\title{
Peningkatan Motivasi Belajar Matematika Siswa Melalui Model Pembelajaran Kooperatif Tipe Teams Assisted Individualization (TAI) pada Siswa Kelas XI IPS 1 SMA Negeri 6 Kerinci
}

\author{
Maisun \\ SMAN 6 Kerinci \\ Correspondence email: maisun.spd.12@gmail.com
}

\begin{abstract}
Abstrak. Penelitian ini bernama penelitian tindakan kelas, Penelitian ini dilakukan karena masih banyak siswa yang kurang memiliki motivasi dalam belajar matematika, oleh karena itu penulis mencoba untuk meningkatkan motivasi belajar matematika dengan menerapkan model Pembelajaran Kooperatif Tipe Teams Assisted Individualization (TAI) yaitu model pembelajaran kooperatif yang menggabungkan pembelajaran kooperatif dengan pembelajaran individual. Penelitian ini bertujuan untuk mengetahui apakah penerapan model pembelajaran Kooperatif Tipe Teams Assisted Individualization (TAI) dapat meningkatkan motivasi belajar siswa yang berhubungan dengan kerjasama, partisipasi, gairah dan semangat belajar Siswa kelas XII IPS 1 SMA Negeri 6 Kerinci. Penelitian ini di bantu oleh rekan sesama guru mata pelajaran matematika yang berperan sebagai kolaborator. Penelitian dilakukan sebanyak dua siklus dimana setiap siklus terdiri dari empat tahapan yaitu : (a). Perencanaan, (b). Pelaksanaan, (c). Observasi, (d). Refleksi. Teknik dalam mengumpulkan data yaitu : a). observasi b). angket, c). tes tertulis. Hasil Analisis data menunjukkan bahwa motivasi belajar matematika siswa meningkat signifikan setelah diterapkan model pembelajaran Kooperatif TAI (Tipe Teams Assisted Individualization). Dari tingkat motivasi belajar siswa dengan penerapan model pembelajaraan kooperatif Tipe TAI (Teams Assisted Individualization) didapatkan hasil siklus I dengan persentase motivasi belajar siswa 58,69\%. Setelah adanya tindakan siklus II persentase meningkat menjadi 75,30\%. Dapat disimpulkan bahwa penggunaan model pembelajatan tipe TAI dapat meningkatkan motivasi belajar siswa. Oleh karena itu di sarankan kepada guru matematika menggunakan metode pembelajaran Kooperatif Tipe Teams Assisted Individualization (TAI) sebagai salah satu solusi untuk mengatasi masalah motivasi belajar siswa dalam belajar matematika.
\end{abstract}

Kata Kunci: Kooperatif Tipe Teams Assisted Individualization (TAI); Motivasi Belajar

Abstract. This research was a classroom action research. The study was conducted because there were some students who were lack of motivation in learning Math Subject. Therefore, the researcher offered Cooperative Team Assisted Individualization (TAI) to improve the students learning motivation on Math Subject. The objective of the research was to figure out whether the method could improve the student's learning motivation related to cooperation, participation, passion and learning enthusiasm at grade XII IPS I SMA N 1 Kerinci. The collaborator of the research was a teacher who taught the same subject. The research was done in two cycles which had three stages; (a) Planning (b) Action (c) Observation, and (d) Reflection. The data were collected by using (a) observation (b) Questionnaire (c) Written test. The data analysis result showed that the student's learning motivation in Math subject improved significantly after Cooperative TAI (Teams Assisted Individualization) was implemented. The student's learning motivation in cycle one was 58,69\%, then in cycle 2 the percentage was 75,30\%. It concluded that the implementation of Cooperative TAI in learning and teaching process on Math Subject improved the student's learning motivation. It was suggested to Math Teacher to apply this method as one of the solutions to cover the student's learning motivation problem on Math Subject.

\section{Keywords: Cooperative TAI (Teams Assisted Individualization); Learning Motivation}

\section{PENDAHULUAN}

Pada hakekatnya matematika itu adalah ilmu yang membantu manusia dalam memahami dan menguasai permasalahan social, ekonomi dan alam. Pembelajaran Matematika menurut Russefendi yang dikutip oleh Erman Suherman (2003) matematika terbentuk sebagai hasil pemikiran manusia yang berhubungan dengan ide proses dan penalaran. Sesuai dengan pengertian dan karakter matematika di atas, matematika merupakan ilmu pengetahuan sebagai sarana berpikir yang meliputi penalaran dan logika, serta objeknya yang bersifat abstrak.

Dalam pembelajaran di sekolah, guru hendaknya memilih dan menggunakan strategi, pendekatan, metode dan teknik yang banyak melibatkan siswa aktif dalam belajar (Erman Suherman, 2003).

Dengan demikian, pembelajaran matematika dapat diartikan sebagai suatu rangkaian kegiatan yang melibatkan guru dan siswa, dimana kegiatan guru ditujukan kepada siswa dalam menyampaikan pengetahuan dan keterampilan serta membimbing dan melatih siswa agar belajar tentang matematika.

Namun kenyataan dilapangan ada banyak permasalahan yang dialami oleh siswa dalam belajar matematika. Dari hasil observasi dan wawancara yang dilaksanakan oleh peneliti pada siswa kelas XII IPS 1 terdapat berbagai permasalahan dalam pembelajaran, antara lain: 
Maisun, Peningkatan Motivasi Belajar Matematika Siswa Melalui Model Pembelajaran Kooperatif Tipe Teams Assisted Individualization (TAI) pada Siswa Kelas XI IPS 1 SMA Negeri 6 Kerinci

Adanya keluhan dari siswa bahwa matematika hanya bikin pusing siswa dan dianggap sebagai momok yang menakutkan bagi siswa, ketika pembelajaran matematika berlangsung sebagian besar siswa tidak berani bertanya, Sebagian siswa tidak membawa dan bahkan ada yang tidak memiliki catatan buku matematika padahal jadwal pada hari tersebut ada mata pelajaran matematika, pada saat pembelajaran masih ada siswa yang berbicara diluar materi pelajaran dengan teman, mengganggu teman lain, pada saat pembelajaran berlangsung adanya siswa yang mengantuk,masih ada siswa yang terlambat ketika jam pelajaran matematika sudah dimulai, urangnya kepercayaan diri dalam menyelesaikan soal yang ditandai dari hasil ulangan harian, dan pekerjaan rumah sering mengharapkan jawaban dari teman,belum nampak adanya usaha yang maksimal dalam menyelesaikan soal,ada beberapa siswa yang tidak mengumpulkan tugas.

Berdasarkan permasalahan di atas tergambar bahwa motivasi belajar siswa masih rendah, perolehan hasil belajar yang dilakukan pada pokok bahasan peluang di kelas XII IPS 1 masih rendah, dari 27 siswa hanya 9 siswa dengan persentase $33,33 \%$ yang hasil belajarnya di atas KKM dengan rata-rata ketuntasan baru mencapai 60.

\section{Motivasi Belajar}

Motivasi belajar adalah sesuatu dorongan dalam diri siswa untuk melakukan suatu pembelajaran agar mendapatkan sesuatu yaitu ilmu, pengalaman, ataupun yang lainnya. (Eka Warna, 2010) disebutkan motivasi belajar merupakan variable yang paling penting, karena proses belajar akan lebih efisien, jika warga belajar yang bersangkutan memiliki keinginan untuk mempelajari sesuatu yang dipikirkannya.

Thornburgh dalam Elida Prayitno (1989) mengemukakan bahwa motivasi dibagi menjadi dua yaitu motivasi intrinsik dan ekstrinsik. Motivasi instrinsik adalah kegiatan bertindak yang disebabkan faktor pendorong diri dalam diri individu. Elida Prayitno (1989), selanjutnya menjelaskan di dalam proses belajar, siswa yang bermotivasi secara intstrinsik dapat dilihat dari kegiatannya yang tekun dalam mengerjakan tugastugas belajar karena merasa perlu dan ingin mencapai tujuan belajar yang sebenarnya. Sedangkan Motivasi ekstrinsik adalah motivasi yang berasal dari luar atau motivasi yang timbul dari pengaruh luar. Motivasi yang berasal dari luar berupa: adanya keinginan memperoleh penghargaan, adanya persaingan antar teman dan adanya dorongan dari guru.

Dari definisi di atas dapat ditarik kesimpulan bahwa untuk mengukur motivasi belajar siswa, dapat dilakukan melalui pengamatan terhadap perubahan sikap dan aktivitas siswa yang menunjukkan adanya peningkatan kesungguhan dan kedisiplinan, kegembiraan dan semangat belajar, sikap terhadap media, aktivitas keterlibatan dalam pembelajaran dan aktivitas siswa dalam menerima dan memahami pelajaran.

Menurut Bruner dalam Dian Mahsunah, dkk (2017) dalam teorinya menyatakan bahwa belajar matematika akan lebih berhasil jika proses pengajaran diarahkan kepada konsep-konsep dan struktur-struktur yang termuat dalam pokok bahasan yang diajarkan, disamping hubungan yang terkait antar konsep-konsep dan struktur-struktur, dengan mengenal konsep dan struktur yang tercakup dalam bahan yang sedang dibicarakan, anak akan memahami materi yang harus dikuasainya itu.

Dari pengertian di atas dapat disimpulkan bahwa pemahaman adalah kemampuan siswa dalam menyelesaikan soal dan menggunakannya pada penerapan situasi lain yang relevan karena adanya latihan yang dapat dilihat dari hasil belajar.

\section{Model Pembelajaran Kooperatif}

Untuk meningkatkan motivasi belajar dan hasil belajar siswa dalam proses belajar mengajar agar siswa lebih mudah dalam memahami konsep yang diajarkan, maka seorang guru harus bisa memilih model pembelajaran yang tepat.

Anita Lie (2005), menyatakan bahwa "Sistem pembelajaran cooperative learning bisa didefinisikan sebagai sistem kerja/belajar kelompok yang terstruktur". Sedangkan menurut Slavin dalam Mohammad Nur (2005), menyatakan bahwa:

Model pembelajaran kooperatif merupakan teknik-teknik kelas praktis yang dapat digunakan guru setiap hari untuk membantu siswanya belajar setiap mata pelajaran, mulai dari keterampilan-keterampilan dasar sampai pemecahan masalah yang kompleks. Dalam model pembelajaran kooperatif, siswanya bekerja dalam kelompok-kelompok kecil saling membantu belajar satu sama lainnya.

Menurut Anita Lie (2005), menyatakan bahwa "Pengelompokan heterogenitas (bermacam ragam) merupakan ciri yang menonjol dalam pembelajaran cooperative learning. Kelompok yang heterogenitas bisa dibentuk dengan memperhatikan keanekaragaman gender, latar belakang sosial, ekonomi serta kemampuan akademis". Dalam penyelesaian tugas kelompok setiap anggota saling bekerja sama dan saling membantu untuk memahami materi belajar. Proses belajar belum dianggap selesai jika salah satu kawan dalam kelompok tersebut belum dapat menyelesaikannya.

Slavin dalam Mohammad Nur (2005) menyatakan "Ada tiga konsep utama model pembelajaran tim siswa, yaitu: penghargaan tim, tanggung jawab individual dan kesempatan yang sama untuk berhasil". Lebih lanjut Roger dan David Johnson dalam Anita Lie (2005) menyatakan bahwa:

Tidak semua kerja kelompok bisa dianggap cooperative learning. Untuk mencapai hasil yang maksimal, lima unsur model pembelajaran gotong 
royong harus diterapkan, yaitu: saling ketergantungan positif, tanggung jawab perseorangan, tatap muka, komunikasi antar anggota, evaluasi proses kelompok.

Dalam model pembelajaran kooperatif dikembangkan diskusi dan komunikasi dengan tujuan agar siswa saling berbagi kemampuan, saling belajar berpikir kritis, saling menyampaikan pendapat, saling membantu belajar, saling menilai kemampuan dan peranan diri sendiri maupun teman lain. Terdapat enam langkah dalam model pembelajaran kooperatif sebagai berikut :

Tabel 1. Langkah-langkah model pembelajaran kooperatif

\begin{tabular}{|c|c|c|}
\hline Langkah & Indikator & Tingkah Laku Guru \\
\hline Langkah 1 & $\begin{array}{l}\text { Menyampaikan } \\
\text { tujuan dan } \\
\text { memotivasi siswa. }\end{array}$ & $\begin{array}{l}\text { Guru menyampaikan } \\
\text { tujuan pembelajaran dan } \\
\text { mengkomunikasikan } \\
\text { kompetensi dasar yang } \\
\text { akan dicapai serta } \\
\text { memotivasi siswa. }\end{array}$ \\
\hline Langkah 2 & $\begin{array}{l}\text { Menyajikan } \\
\text { informasi }\end{array}$ & $\begin{array}{l}\text { Guru menyajikan } \\
\text { informasi kepada siswa }\end{array}$ \\
\hline Langkah 3 & $\begin{array}{l}\text { Mengorganisasikan } \\
\text { siswa ke dalam } \\
\text { kelompok-kelompok } \\
\text { belajar }\end{array}$ & $\begin{array}{l}\text { Guru menginformasikan } \\
\text { pengelompokan siswa. }\end{array}$ \\
\hline Langkah 4 & $\begin{array}{l}\text { Membimbing } \\
\text { kelompok belajar. }\end{array}$ & $\begin{array}{l}\text { Guru memotivasi serta } \\
\text { memfasilitasi kerja } \\
\text { siswa dalam kelompok- } \\
\text { kelompok belajar. }\end{array}$ \\
\hline Langkah 5 & Evaluasi. & $\begin{array}{l}\text { Guru mengevaluasi hasil } \\
\text { belajar tentang materi } \\
\text { pembelajaran yang telah } \\
\text { dilaksanakan. }\end{array}$ \\
\hline Langkah 6 & $\begin{array}{l}\text { Memberikan } \\
\text { penghargaan. }\end{array}$ & $\begin{array}{l}\text { Guru memberi } \\
\text { penghargaan hasil } \\
\text { belajar individual dan } \\
\text { kelompok. }\end{array}$ \\
\hline
\end{tabular}

Sumber: Made Wena, Strategi Pembelajaran Inovatif Kontemporer, Bumi Aksara, Jakarta, 2009

\section{Pembelajaran Kooperatif Teams Assisted Individualization (TAI)}

Pembelajaran kooperatiftipe TAI (Teams Assisted Individualization) yang dikembangkan oleh Slavin (2008) mengkombinasikan keunggulan pembelajaran kooperatif dan pembelajaran individual. TAI (Teams Assisted Individualization) dirancang untuk mengatasi kesulitan belajar siswa secara individu. Oleh karena itu, kegiatan pembelajarannya lebih banyak digunakan untuk pemecahan masalah.

Ciri khas pada tipe TAI (Teams Assisted Individualization) ini adalah setiap siswa secara individual belajar materi pembelajaran yang sudah dipersiapkan oleh guru. Hasil dari individu dibawa kekelompok-kelompok untuk didiskusikan dan saling dibahas oleh anggota kelompok, dan semua anggota kelompok bertanggung jawab atas keseluruhan jawaban sebagai tanggungjawab bersama. Model ini dirancang untuk menggabungkan insentif motivasional dari penghargaan kelompok dengan program pembelajaran individual yang cocok dengan tingkat keterampilan setiap siswa (menggabungkan pembelajaran kooperatif dengan pembelajaran individu). TAI (Teams Assisted Individualization) dirancang untuk menyelesaikan masalah-masalah teoritis dan praktis dari sistem pengajaran individual sebagai berikut.

1. Dapat meminimalisir keterlibatan guru dalam pemeriksaan dan pengelolaan rutin.

2. Guru setidaknya akan menghabiskan separuh dari waktunya untuk mengajar kelompok-kelompok kecil.

3. Operasional program tersebut disusun secara sederhana.

4. Para siswa akan termotivasi untuk mempelajari materi-materi yang diberikan dengan tepat dan akurat, dan tidak akan bisa berbuat curang atau menyelesaikan dengan jalan pintas.

5. Tersedianya banyak cara pengecekan penguasaan supaya para siswa jarang menghabiskan waktu mempelajari kembali materi yang sudah mereka kuasai atau mengahadapi kesulitan serius yang membutuhkan bantuan guru.

6. Para siswa akan dapat melakukan pengecekan satu sama lain, sekalipun siswa yang mengecek kemampuannya ada di bawah siswa yang dicek dalam rangkaian pengajaran, dan prosedur pengecekan akan cukup sederhana dan tidak menganggu si pengecek.

7. Program mudah dipelajari baik oleh guru maupun siwa, tidak mahal, fleksibel, dan tidak membutuhkan guru tambahan ataupun tim guru.

8. Dengan membuat para siswa bekerja dalam kelompok-kelompok kooperatif, dengan status yang sejajar, program ini akan membangun kondisi untuk terbentuknya sikap-sikap positif terhadap siswa-siswa yang cacat secara akademik dan di antara para siswa dari latar belakang ras atau etnik berbeda.

Menurut Slavin (2008) langkah-langkah pembelajaran kooperatif tipe TAI (Teams Assisted Individualization) sebagai berikut.

1. Guru memberikan tugas kepada siswa untuk mempelajari materi pembelajaran secara individual yang sudah dipersiapkan oleh guru

2. Guru memberikan kuis (pretest) secara individual kepada siswa untuk mendapatkan skor dasar atau skor awal

3. Guru membentuk beberapa kelompok. Setiap kelompok terdiri dari 4-5 siswa dengan kemampuan yang berbeda-beda baik tingkat kemampuan (tinggi, sedang dan rendah) Jika mungkin anggota kelompok berasal dari ras, budaya, suku yang berbeda serta kesetaraan jender

4. Hasil belajar siswa secara individual didiskusikan dalam kelompok. Dalam diskusi kelompok, setiap anggota kelompok saling memeriksa jawaban teman satu kelompok 
5. Guru memfasilitasi siswa dalam membuat rangkuman, mengarahkan, dan memberikan penegasan pada materi pembelajaran yang telah dipelajari

6. Guru memberikan kuis (post test) kepada siswa secara individual

7. Guru memberi penghargaan pada kelompok berdasarkan perolehan nilai peningkatan hasil belajar individual dari skor dasar ke skor kuis berikutnya (terkini).

\section{METODE}

\section{Jenis dan desain Penelitian}

Penelitian ini merupakan Penelitian Tindakan Kelas (PTK) yang dilakukan langsung oleh teman sejawat yang ikut mengamati jalannya penelitian.

\section{Waktu Penelitian}

Penelitian dilakukan pada bulan 12 Januari s.d 31 Maret 2020 pada semester Genap tahun pelajaran 2019/2020.

\section{Subjek Penelitian}

Subjek pada penelitian ini adalah seluruh siswa pada kelas XII IPS 1, yang berjumlah 27 siswa yang terdiri dari 14 siswa laki-laki dan 13 siswa perempuan.

\section{Sumber Data}

Sumber data penelitian berasal dari 1) Tempat berlangsungnya kegiatan pembelajaran di kelas, 2) Peserta didik kelas XII IPS 1, 3) Buku daftar nilai.

\section{Rancangan Penelitian}

Penelitian ini merupakan penelitian tindakan kelas, yang dilaksanakan dalam dua siklus Adapun tahapan-tahapannya adalah sebagai berikut:

\section{Perencanaan}

Pada tahap perencanaan ini dilakukan persiapan yang berhubungan dengan Pelaksanaan model pembelajaran TAI (Teams Assisted Individualization) seperti Identifikasi masalah, pembuatan rencana pembelajaran, pembuatan lembar kerja siswa, pembuatan lembar pengamatan siswa dan guru, pembuatan Angket motivasi belajar.

\section{Pelaksanaan Tindakan}

Pelaksanaan tindakan merupakan kegiatan dilaksanakannya skenario pembelajaran yang telah direncanakan. Adapun tindakan yang dilakukan oleh guru adalah memberi tugas mandiri kepada siswa, membentuk kelompok, membimbing siswa memberikan penegasan pada materi pembelajaran yang telah dipelajari, serta memberikan tes diakhir siklus.

3. Pengamatan

Pengamatan adalah suatu kegiatan mengamati jalannya pelaksanaan tindakan untuk memantau sejauh mana efek tindakan pembelajaran dengan menggunakan Model Pembelajaran TAI (Teams Assisted Individualization) pada pokok materi Peluang. Pengumpulan data pada tahap ini meliputi data motivasi belajar dan nilai hasil belajar siswa

4. Refleksi

Dengan data observasi dan angket berdasarkan tindakan peneliti dapat direfleksi apakah dengan model Pembelajaran Kooperatif tipe TAI (Teams Assisted Individualization) dapat meningkatkan motivasi belajar dan hasil belajar siswa. Hasil dari refleksi adalah diadakannya perbaikan terhadap perencanaan yang telah dilaksanakan, yang akan digunakan untuk memperbaiki kinerja guru pada siklus selanjutnya.

\section{Teknik dan Instrumen Pengumpul Data}

Teknik Pengumpulan Data Teknik yang digunakan dalam pengumpulan data adalah sebagai berikut:

1. Observasi, Observasi dilakukan oleh teman sejawat peneliti dengan cara melakukan pengamatan dan pencatatan aktivitas siswa, guru, selama proses pembelajaran matematika. Observasi dilakukan dengan menggunakan lembar observasi yang telah dipersiapkan.

2. Angket, Angket adalah alat pengumpulan data secara tertulis yang berisi daftar pernyataan yang disusun secara khusus dan digunakan untuk menggali dan menghimpun keterangan dan/atau informasi sebagaimana dibutuhkan. Dalam penelitian ini angket yang digunakan adalah angket motivasi.

3. Tes Tertulis, tes tertulis dilakukan setiap akhir siklus untuk melihat kemampuan siswa dalam memahami konsep.

\section{Analisis Data}

Data yang terkumpul berupa hasil angket, observasi. Data yang diperoleh dianalisis secara deskriptif untuk mengetahui pelaksanaan dan hambatanhambatan yang terjadi selama pembelajaran. Tahapantahapan dalam proses analisis data adalah sebagai berikut:

1. Reduksi data Reduksi data dalam penelitian ini merupakan proses penyeleksian dan penyederhanaan data melalui seleksi, pemfokusan dan pengabstrakan data mentah ke pola yang lebih terarah dan dikelompokkan berdasarkan kepentingan pada rumusan masalah.

2. Penyajian data Penyajian data dilakukan dalam rangka penyusunan informasi secara sistematis mulai dari perencanaan, pelaksanaan tindakan dan refleksi pada masing-masing siklus.

3. Penarikan kesimpulan adalah pemberian makna pada data yang diperoleh dari penyajian data. Penarikan kesimpulan dilakukan berdasarkan hasil dari semua data yang telah diperoleh. 
Maisun, Peningkatan Motivasi Belajar Matematika Siswa Melalui Model Pembelajaran Kooperatif Tipe Teams Assisted Individualization (TAI) pada Siswa Kelas XI IPS 1 SMA Negeri 6 Kerinci

Adapun secara lebih rinci analisis datanya adalah sebagai berikut:

1. Analisis data hasil observasi Lembar observasi untuk mengetahui keterlaksanaan pembelajaran dengan menggunakan metode Pembelajaran Kooperatif tipe TAI (Teams Assisted Individualization) yang menciptakan lingkungan belajar yang efektif, dan kerjsama antar sesama anggota kelompok,dengan cara menggunakan unsur yang ada pada siswa, guru dan lingkungan belajarnya melalui interaksi yang terjadi di dalam kelas.

2. Skala yang digunakan dalam lembar observasi ini menggunakan skala Guttman, observer membubuhkan tanda cek $(\sqrt{ })$ pada langkah-langkah pembelajaran yang terlaksana pada kolom "ya" dan "tidak". Dan dari setiap aspek yang terlaksana (pada kolom "ya") diberi skor 1, jika tidak terlaksana (pada kolom "tidak") diberi skor 0 .

Kemudian dihitung persentase keterlaksanaannya, dengan rumus:

Skala yang digunakan untuk lembar observasi

$P=\frac{F}{A} X 100 \%$

Keterangan:

$\mathrm{P}=$ Persentase Keterlaksanaan Pembelajaran

$\mathrm{F}=$ Jumlah Skor Keterlaksanaan Pembelajaran

A = Jumlah Skor Maksimal Keterlaksanaan

Pembelajaran

Untuk mengetahui pemahaman siswa, setelah tindakan selesai, kepada siswa diberikan tes akhir siklus. Tujuannya untuk mengetahui tingkat pemahaman siswa setelah pelaksanaan tindakan. Dari analisis hasil tes akhir siklus, dapat diketahui tercapai tidaknya indikator keberhasilan tindakan yang telah ditetapkan.Untuk mengetahui perubahan hasil tindakan, jenis data yang bersifat kuantitatif, dianalisis menggunakan rumus data kuantitatif dalam penelitian tindakan kelas yaitu:

$$
P=\frac{\text { PostRate }- \text { BaseRate }}{\text { BaseRate }} \times 100 \%
$$

Keterangan :

$P \quad=$ Persentase peningkatan

Post Rate $=$ Nilai rata-rata setelah tindakan

Base Rate = Nilai rata-rata sebelum tindakan

Pedoman Analisis data pengisian angket motivasi belajar matematika siswa

Tabel 2. Skala Penskoran Angket Motivasi Belajar Matematika

\begin{tabular}{ccccc}
\hline \multirow{2}{*}{ Pernyataan } & \multicolumn{4}{c}{ Skor Jawaban } \\
\cline { 2 - 5 } & Selalu & Sering & $\begin{array}{c}\text { Kadang- } \\
\text { kadang }\end{array}$ & $\begin{array}{c}\text { Tidak } \\
\text { pernah }\end{array}$ \\
\hline Positif & 4 & 3 & 2 & 1
\end{tabular}

$\begin{array}{llll}\text { Negatif } & 1 & 2 & 3\end{array}$

Sumber: Nana Syaodih Sukmadinata 2009.

Cara menghitung persentase Skor aspek sebagai berikut:

$P=\frac{F}{A} X 100 \%$

Keterangan:

$\mathrm{P}=$ Persentase Motivasi

$\mathrm{F}=$ Jumlah Skor Perolehan Siswa

A = Jumlah Skor Maksimal

Jumlah Skor yang diperoleh kemudian dikualifikasikan untuk menentukan seberapa besar motivasi siswa dalam mengikuti proses Pembelajaran.

Tabel 3. Kualifikasi Persentase Motivasi Belajar Siswa

\begin{tabular}{|c|c|}
\hline Persentase & Kriteria \\
\hline $75 \% \leq \bar{X} \leq 100 \%$ & Tinggi \\
\hline $50 \% \leq \bar{X} \leq 74,99 \%$ & Sedang \\
\hline $25 \% \leq \bar{X} \leq 49,99 \%$ & Rendah \\
\hline
\end{tabular}

Sumber: Suharsimi Arikunto. 2006

Analisis terhadap tes akhir siklus dan hasil observasi dan hasil pengolahan angket digunakan pada tahap refleksi, sebagai dasar perencanaan tindakan pada siklus berikutnya. Sehingga teknik analisis yang dilakukan dalam penelitian ini adalah diskriptif.

\section{Indikator Kinerja}

Indikator keberhasilan dalam penelitian ini adalah:

1. Pelaksanaan pembelajaran matematika sesuai ketentuan yaitu dengan menggunakan Kooperatif tipe TAI (Teams Assisted Individualization) Dimana persentase rata-rata hasil observasi mencapai $\geq 75 \%$.

2. Rata-rata persentase motivasi belajar matematika siswa secara keseluruhan berada pada kriteria tinggi $(75 \% \leq \bar{X} \leq 100 \%)$

3. Penelitian ini dikatakan berhasil apabila dari tindakan pertama ke tindakan kedua terjadi peningkatan persentase yang signifikan ditinjau dari motivasi belajar dan pemahaman matematika siswa setidaknya kenaikan lebih dari $10 \%$.

\section{HASIL DAN PEMBAHASAN Pra Siklus}

Kondisi awal tingkat Motivasi Belajar siswa kelas XII IPS 1 SMA Negeri 6 Kerinci semester Genap tahun pelajaran 2019/2020 berada pada kriteria rendah , berdasarkan hasil Observasi motivasi belajar yang diamati peneliti, maka akan dilakukan tindakan dalam rangka meningkatkan kualitas pembelajaran yang dibatasi pada tingkat pemahaman dan motivasi belajar peserta didik. Tindakan tersebut berupa penggunaan 
Maisun, Peningkatan Motivasi Belajar Matematika Siswa Melalui Model Pembelajaran Kooperatif Tipe Teams Assisted Individualization (TAI) pada Siswa Kelas XI IPS 1 SMA Negeri 6 Kerinci

model pembelajaran kooperatif tipe TAI (Teams Assisted Individualization).

\section{Siklus I}

Pada siklus I, saat dilaksanakan diskusi siswa terlihat belum begitu aktif dalam kegiatan pembelajaran. Ada beberapa siswa yang sibuk bermain dan mengobrol dengan teman atau beraktivitas sendiri saat berdiskusi kelompok.

Penghargaan kelompok diberikan berdasarkan rata-rata nilai peningkatan hasil lembar kerja yang diperoleh masing-masing kelompok dengan memberikan predikat cukup, baik, sangat baik, dan sempurna. Kriteria peningkatan nilai kelompok bisa dilihat pada tabel berikut ini:

Tabel 4. Skor Capaian Nilai rata-rata peningkatan Kegiatan kelompok Siklus I

\begin{tabular}{cccc}
\hline No. & Nama & $\begin{array}{c}\text { Peningkatan } \\
\text { Nilai Rata-rata }\end{array}$ & $\begin{array}{c}\text { Penghargaan } \\
\text { Kriteria } \\
\text { Kelompok }\end{array}$ \\
\hline 1. & Kelompok 1 & 7,5 & Baik \\
2. & Kelompok 2 & 5,75 & Cukup \\
3. & Kelompok 3 & 6,8 & Cukup \\
4. & Kelompok 4 & 5,4 & Cukup \\
5. & Kelompok 5 & 3,6 & Cukup \\
6. & Kelompok 6 & 6,26 & Cukup \\
\hline
\end{tabular}

Sumber: Pengolahan Data Hasil tes Siklus 1 siswa di kelompok

Dari Hasil tes unit siklus 1 dengan penerapan model pembelajaran kooperatif tipe TAI (Teams Assisted Individualization) pada sub pokok bahasan Peluang diperoleh hasil seperti yang terdapat pada tabel di bawah ini :

Tabel 5. Skor Capaian Nilai Tes Unit (Tes Akhir Siklus 1)

\begin{tabular}{ccccc}
\hline \multirow{2}{*}{$\begin{array}{c}\text { Indikator } \\
\text { nilai }\end{array}$} & \multicolumn{2}{c}{ Pra Siklus } & \multicolumn{2}{c}{ Siklus 1 } \\
\cline { 2 - 5 } & $\begin{array}{c}\text { Jumlah } \\
\text { siswa }\end{array}$ & $\begin{array}{c}\text { Persentase } \\
(\boldsymbol{\%})\end{array}$ & $\begin{array}{c}\text { Jumlah } \\
\text { siswa }\end{array}$ & $\begin{array}{c}\text { Persentase } \\
(\boldsymbol{\%})\end{array}$ \\
\hline$\geq \mathrm{KKM}$ & 9 & 33,33 & 18 & 66,67 \\
$<\mathrm{KKM}$ & 18 & 66,67 & 9 & 33,33 \\
Jumlah & $\mathbf{2 7}$ & $\mathbf{1 0 0}$ & $\mathbf{2 7}$ & $\mathbf{1 0 0}$ \\
\hline
\end{tabular}

Sumber: Data Hasil Tes Akhir Siklus 1

Dari tabel di atas diketahui bahwa siswa yang memiliki nilai di atas KKM dari ketentuan sekolah yaitu 70 sebelum adanya tindakan sebanyak 9 orang siswa dengan rata-rata nilai 60 dengan persentase $33,33 \%$.Setelah adanya tindakan rata-rata nilai meningkat menjadi 72 dengan jumlah siswa yang tuntas meningkat menjadi 18 orang siswa dengan persentase $66,67 \%$.

Hasil Observasi terhadap tingkat motivasi siswa setelah penerapan model pembelajaran kooperatif tipe TAI (Teams Assisted Individualization) pada pokok bahasan peluang dalam pembelajaran pada siklus I yaitu dapat dilihat pada tabel berikut:
Tabel 6. Hasil Observasi motivasi belajar siswa siklus I

\begin{tabular}{|c|c|c|}
\hline Indikator observasi & $\begin{array}{c}\text { Jumlah } \\
\text { Siswa }\end{array}$ & $\begin{array}{c}\text { Persentase } \\
(\%)\end{array}$ \\
\hline Siswa antusias dalam belajar & 15 & 55,56 \\
\hline siswa yang memperhatikan guru & 12 & 44,44 \\
\hline $\begin{array}{l}\text { siswa yang mengerjakan soal atau } \\
\text { tugas dari guru }\end{array}$ & 15 & 55,56 \\
\hline $\begin{array}{l}\text { siswa yang memberikan pendapat } \\
\text { dan bertanya }\end{array}$ & 6 & 22,22 \\
\hline kualitas pertanyaan Siswa & 4 & 14,48 \\
\hline kerjasama dalam kegiatan kelompok & 15 & 55,56 \\
\hline Rata-rata Persentase & & 41,30 \\
\hline
\end{tabular}

Sumber : Hasil Pengolahan Data Observasi siklus 1

Berdasarkan Hasil Observasi terhadap tingkat motivasi siswa setelah penerapan model pembelajaran kooperatif tipe TAI (Teams Assisted Individualization) menunjukkan motivasi belajar siswa masih berada pada kriteria rendah.

Hasil Pengolahan Angket Motivasi Belajar dapat dilihat pada tabel di bawah ini :

Tabel 7. Persentase Penskoran Angket Motivasi Belajar

\begin{tabular}{|c|c|c|}
\hline \multirow[b]{2}{*}{ Indikator Angket } & \multicolumn{2}{|c|}{ Siklus I } \\
\hline & $\begin{array}{l}\text { Persentase } \\
(\%)\end{array}$ & Kategori \\
\hline Ketekunan menghadapi tugas & $55,56 \%$ & Sedang \\
\hline $\begin{array}{l}\text { Keuletan dalam menghadapi } \\
\text { kesulitan }\end{array}$ & $44,44 \%$ & Rendah \\
\hline $\begin{array}{l}\text { Senang dan rajin, penuh } \\
\text { semangat, dan tidak cepat } \\
\text { bosan dengan tugas-tugas rutin }\end{array}$ & $62,96 \%$ & Sedang \\
\hline Dorongan untuk berprestasi & 70,37 & Sedang \\
\hline $\begin{array}{l}\text { Keinginan mendalami lebih } \\
\text { jauh materi yang dipelajari }\end{array}$ & 48,15 & Rendah \\
\hline $\begin{array}{l}\text { Usaha untuk berprestasi sebaik } \\
\text { mungkin }\end{array}$ & 74,07 & Sedang \\
\hline $\begin{array}{l}\text { Mengejar tujuan jangka } \\
\text { panjang }\end{array}$ & $80,08 \%$ & Tinggi \\
\hline $\begin{array}{l}\text { Dapat } \\
\text { mempertanggungjawabkan } \\
\text { pendapat-pendapatnya }\end{array}$ & $55,56 \%$ & Sedang \\
\hline $\begin{array}{l}\text { Senang mencari soal dan } \\
\text { memecahkannya }\end{array}$ & $37,04 \%$ & Rendah \\
\hline $\begin{array}{l}\text { Rata-rata } \\
\text { Keseluruhan }\end{array}$ & $58,69 \%$ & Sedang \\
\hline
\end{tabular}

Sumber : Hasil Pengolahan Data Angket siklus 1

Secara umum tingkat motivasi siswa masih di bawah nilai rata-rata. Hasil observasi dan pengolahan angket, tingkat motivasi siswa dalam belajar masih berada di bawah 75\%, hasil observasi terhadap guru, kemampuan guru mengelola kelas masih kurang sehingga alokasi waktu kurang sesuai. Beberapa kekurangan yang terdapat pada tindakan Siklus I akan diperbaiki dalam tindakan selanjutnya yaitu Siklus II.

\section{Siklus 2}

Siklus kedua ini teridiri dari empat rangkaian yaitu perencanaan, tindakan, pengamatan dan refleksi. 
Maisun, Peningkatan Motivasi Belajar Matematika Siswa Melalui Model Pembelajaran Kooperatif Tipe Teams Assisted Individualization (TAI) pada Siswa Kelas XI IPS 1 SMA Negeri 6 Kerinci

Berdasarkan hasil analisis dan refleksi dari tindakan pada proses kegiatan belajar mengajar siklus 1, maka perencanaan tindakan untuk siklus II sebagai berikut :

1) Mengoptimalkan pemberian motivasi baik pengulangan materi maupun dorongan untuk meningkatkan motivasi belajar siswa dalam pembelajaran.

2) Memberikan lebih banyak kesempatan kepada siswa untuk bertanya dan menjawab, menyampaikan pendapatnya, sedangkan guru hanya bertindak sebagai fasilitator.

3) Memantau lebih intensif kepada setiap kelompok agar mereka saling berdiskusi dan bekerja sama dengan setiap anggota kelompok.

Penghargaan kelompok diberikan berdasarkan rata-rata nilai peningkatan hasil dan tes akhir siklus yang diperoleh masing-masing kelompok dengan memberikan predikat cukup, baik, sangat baik, dan sempurna. Nilai rata-rata peningkatan kelompok dan kriteria penghargaan kelompok dapat dilihat dari tabel berikut :
Tabel 8. Skor Capaian Nilai rata-rata peningkatan Kegiatan kelompok Siklus II (dua)

\begin{tabular}{cccc}
\hline No. & Nama & $\begin{array}{c}\text { Peningkatan } \\
\text { Nilai Rata-rata }\end{array}$ & $\begin{array}{c}\text { Penghargaan } \\
\text { Kriteria } \\
\text { Kelompok }\end{array}$ \\
\hline 1. & Kelompok 1 & 13 & Sangat Baik \\
2. & Kelompok 2 & 10,25 & Baik \\
3. & Kelompok 3 & 8,4 & Baik \\
4. & Kelompok 4 & 7,4 & Baik \\
5. & Kelompok 5 & 14,2 & Sangat baik \\
6. & Kelompok 6 & 4,25 & Cukup \\
\hline
\end{tabular}

Sumber: Pengolahan Data Hasil tes Siklus II siswa di kelompok

Berdasarkan hasil tabel di atas setelah dilakukan tindakan pembelajaran kooperatif tipe TAI (Team Assisted Individualization) menunjukkan peningkatan kegiatan kelompok yang signifikan dari siklus I ke siklus II. Hasil tes unit siswa setelah penggunaan model pembelajaran kooperatif tipe TAI (Team Assisted Individualization) pada sub pokok bahasan Peluang pada siklus II sebagai berikut.

Tabel 9. Skor Capaian Nilai Tes Unit (Tes Akhir Siklus I dan II)

\begin{tabular}{lccccc}
\hline \multirow{2}{*}{ Indikator nilai } & \multicolumn{2}{c}{ SiklusI } & \multicolumn{2}{c}{ Siklus II } & \multirow{2}{*}{ Peningkatan $(\%)$} \\
\cline { 2 - 5 } & Jumlah siswa & Persentase $(\%)$ & Jumlah siswa & Persentase $(\%)$ & 11,11 \\
\hline KKM & 18 & 66,67 & 21 & 77,78 & $-11,11$ \\
KKM & 9 & 33,33 & 6 & 22,22 & $\mathbf{1 0 0}$ \\
Jumlah & $\mathbf{2 7}$ & $\mathbf{1 0 0}$ & $\mathbf{2 7}$ & \\
\hline
\end{tabular}

Dari tabel diketahui bahwa siswa yang memiliki nilai tes akhir (tes unit) siklus II diatas KKM meningkat $11,11 \%$ setelah adanya tindakan II dengan model pembelajaran kooperatif tipe TAI (Team Assisted Individualization).

Tabel 10. Hasil Observasi motivasi belajar Siklus II

\begin{tabular}{lcc}
\hline \multicolumn{1}{c}{ Indikator observasi } & $\begin{array}{c}\text { Jumlah } \\
\text { Siswa }\end{array}$ & $\begin{array}{c}\text { Persentase } \\
(\%)\end{array}$ \\
\hline $\begin{array}{l}\text { Siswa antusias dalam belajar } \\
\text { siswa yang memperhatikan guru }\end{array}$ & 20 & 74,07 \\
$\begin{array}{l}\text { siswa yang mengerjakan soal atau } \\
\text { tugas dari guru }\end{array}$ & 18 & 74,07 \\
$\begin{array}{l}\text { siswa yang memberikan pendapat dan } \\
\text { bertanya }\end{array}$ & 20 & 74,07 \\
kualitas pertanyaan Siswa & & \\
kerjasama dalam kegiatan kelompok & 22 & 81,48 \\
Rata-rata Persentase & 22 & 81,48 \\
\hline
\end{tabular}

Sumber: Hasil Pengolahan Data Observasi siklus 1I

Berdasarkan Hasil Observasi terhadap tingkat motivasi siswa setelah penerapan model pembelajaran kooperatif tipe TAI (Teams Assisted Individualization) menunjukkan peningkatan yang signifikan dimana motivasi belajar siswa meningkat pada kriteria Tinggi. Berdasarkan Hasil Pengolahan Angket Motivasi Belajar dapat dilihat pada tabel di bawah ini :
Tabel 11. Persentase Penskoran Angket Motivasi Belajar

\begin{tabular}{|c|c|c|}
\hline \multirow[b]{2}{*}{ Indikator Angket } & \multicolumn{2}{|c|}{ Siklus II } \\
\hline & $\begin{array}{l}\text { Persentase } \\
(\%)\end{array}$ & Kategori \\
\hline Ketekunan menghadapi tugas & 74,07 & Sedang \\
\hline $\begin{array}{l}\text { Keuletan dalam menghadapi } \\
\text { kesulitan }\end{array}$ & 74,07 & Sedang \\
\hline $\begin{array}{l}\text { Senang dan rajin, penuh semangat, } \\
\text { dan tidak cepat bosan dengan } \\
\text { tugas-tugas rutin }\end{array}$ & 74,07 & Sedang \\
\hline Dorongan untuk berprestasi & 85,18 & Tinggi \\
\hline $\begin{array}{l}\text { Keinginan mendalami lebih jauh } \\
\text { materi yang dipelajari }\end{array}$ & 66,67 & Sedang \\
\hline $\begin{array}{l}\text { Usaha untuk berprestasi sebaik } \\
\text { mungkin }\end{array}$ & 81,48 & Tinggi \\
\hline Mengejar tujuan jangka panjang & 81,48 & Tinggi \\
\hline $\begin{array}{l}\text { Dapat mempertanggungjawabkan } \\
\text { pendapat-pendapatnya }\end{array}$ & 66,67 & Sedang \\
\hline $\begin{array}{l}\text { Senang mencari soal dan } \\
\text { memecahkannya }\end{array}$ & 74,07 & Sedang \\
\hline $\begin{array}{l}\text { Rata-rata } \\
\text { Keseluruhan }\end{array}$ & 75,30 & Tinggi \\
\hline
\end{tabular}

Sumber: Hasil Pengolahan Data Angket motivasi belajar siklus $1 \mathrm{I}$

Berdasarkan tabel di atas tingkat motivasi siswa meningkat secara signifikan dari hasil pengolahan 
Maisun, Peningkatan Motivasi Belajar Matematika Siswa Melalui Model Pembelajaran Kooperatif Tipe Teams Assisted Individualization (TAI) pada Siswa Kelas XI IPS 1 SMA Negeri 6 Kerinci

angket, tingkat motivasi siswa dalam belajar sudah melebihi $75 \%$, atau berada pada kategori tinggi.

\section{Pembahasan \\ Pra Siklus}

Pada kegiatan pra siklus, rata-rata nilai Pretest siswa adalah 60 dengan jumlah siswa yang memiliki nilai di atas KKM sebanyak 9 orang atau persentase mencapai $33,33 \%$. Dari hasil observasi kegiatan pra siklus, maka akan dilaksanakan tindakan I dengan penerapan model pembelajaran kooperatif tipe TAI (Teams Assisted Individualization) didapatkan hasil siklus I.

\section{Siklus I}

Pada Kegiatansiklus I capaian rata-rata nilai tes akhir siklus I siswa adalah 72 dengan siswa yang memiliki nilai di atas KKM sebanyak 18 orang atau persentase mencapai $66,67 \%$. Jika dibandingkan dengan hasil kegiatan pra siklus, nilai rata-rata siswa dan banyaknya siswa yang memperoleh nilai di atas KKM meningkat. Akan tetapi peningkatan nilai siswa belum menunjukkan kenaikan yang cukup siknifikan. Sehingga perlu dilakukan tindakan lanjutan dengan melihat refleksi dari beberapa hambatan dari siklus I dan menindaklanjuti hasil refleksi dengan perbaikan dari tindakan siklus I. Motivasi Belajar Siswa juga mengalami peningkatan yang signifikan berdasarkan hasil observasi pada siklus I rata-rata persentase baru mencapai 41,30\% dengan kategori rendah, sedangkan hasil pengolahan data Angket motivasi belajar siswa pada tindakan I persentase baru mencapai 58,69\% dengan kategori rendah,

\section{Siklus II}

Pada siklus II akan dilaksanakan kembali model pembelajaran kooperatif tipe TAI dengan kondisi kelompok yang sama seperti pada siklus I. Setelah adanya tindakan siklus II, diperoleh hasil rata-rata nilai tes akhir siklus II adalah 78 dengan siswa yang memiliki nilai di atas KKM sebanyak 21 orang dengan persentase mencapai $77,78 \%$. Pada motivasi belajar siswa siklus 2 setelah adanya tindakan menunjukkan adanya peningkatan pada persentase hasil observasi $75,30 \%$. Sedangkan hasil pengolahan data Angket motivasi belajar siswa pada siklus ke dua meningkat menjadi $75.30 \%$.

Berdasarkan hasil dari perubahan ketuntasan hasil belajar siswa dan motivasi belajar siswa dapat disimpulkan penerapan model pembelajaran kooperatif tipe TAI (Teams Assisted Individualization) dapat meningkatkan motivasi belajar dan pemahaman siswa.

\section{SIMPULAN}

Berdasarkan hasil penelitian dan pembahasan dapat disimpulkan bahwa penerapan model pembelajaran kooperatif tipe TAI (Teams Assisted
Individualization) dapat meningkatkan motivasi belajar dan pemahaman siswa khususnya pada pokok bahasan Peluang.

Rata-rata ketuntasan belajar siswa sebelum adanya tindakan baru mencapai 60 dengan persentase ketuntasan $33,33 \%$ dan setelah penerapan model pembelajaran kooperatif tipe TAI (Teams Assisted Individualization) pada tindakan I rata-rata hasil tes akhir siklus I meningkat menjadi 72 dengan persentase 66,67\% dikarenakan belum mencapai target sehingga dilakukan tindakan ke dua, capaian rata-rata nilai tes akhir siklus II mencapai 78 dengan persentase $77,78 \%$.

Motivasi Belajar Siswa meningkat signifikan berdasarkan hasil observasi pada siklus I rata-rata persentase baru mencapai 44,30\% dengan kategori rendah, pada siklus 2 setelah adanya tindakan menunjukkan adanya peningkatan pada persentase hasil observasi $75,30 \%$. Sedangkan hasil pengolahan data Angket motivasi belajar siswa pada tindakan I persentase baru mencapai $58,69 \%$ dengan kategori rendah, pada siklus ke dua meningkat menjadi $75.30 \%$ dengan kategori Tinggi.

Berdasarkan hasil persentase, terjadi peningkatan hasil belajar dan motivasi belajar matematika siswa dan telah mencapai target, sehingga peneliti menghentikan siklusnya dan disarankan kepada guru mata pelajaran matematika agar menggunakan model pembelajaran kooperatif tipe TAI (Teams Assisted Individualization).

\section{DAFTAR PUSTAKA}

Dian Mahsunah, dkk. 2017. Sumber Belajar Penunjang PLPG .Padang: BPSDMPK

Erman Suherman dkk. 2003. Strategi Pembelajaran Matematika Kontemporer. Bandung: UPI

Eka Warna.2010. Penelitian TindakanKelas: Jakarta Gaung Persada

Lie,Anita.2005.Cooperative Learning-Mempraktikkan Cooperative Learning di Ruang-ruang Kelas.Jakarta:Grasindo.

Made Wena.2009. Strategi pembelajaran inovatif kontemporer. Jakarta: Bumi Aksara

Nana Syaodih Sukmadinata. 2009. Metode Penelitian Pendidikan. Bandung: PT. Remaja Rosdakarya.

Nur,Mohammad.2005.Pembelajaran Kooperatif.Surabaya:Pusat Sains dan Matematika UNESA

Prayitno, Elida. 1989. Motivasi dalam Belajar. Jakarta: Departemen Pendidikan Kebudayaan, Direktur Jenderal Pendidikan Tinggi

Slavin, Robert E. 2008. Cooperative Learning: Teori, Riset dan Praktik. Bandung: Nusa Media

Suharsimi Arikunto. 2006. Prosedur Penelitian; Suatu Pendekatan Praktik. Jakarta: Rineka Cipta 